\title{
A Child with Celiac Artery Compression Syndrome Diagnosed on the Basis of a Careful Physical Examination
}

\section{Dikkatli Fizik Inceleme ile Çölyak Arter Kompresyon Sendromu Tanısı Konulan Çocuk Olgu}

\author{
๑ Vildan Güngörer, ๑ Ahmet Sert* , ๑ Mehmet Öztürk** ๑ Şükrü Arslan \\ Selçuk University Faculty of Medicine, Department of Pediatric Romatology, Konya, Turkey \\ *Selçuk University Faculty of Medicine, Department of Pediatric Cardiology, Konya, Turkey \\ **Selçuk University Faculty of Medicine, Department of Radiology, Konya, Turkey
}

\section{Abstract}

Celiac artery compression syndrome is a clinical condition caused by compression of the celiac axis by the surrounding tissues. Patients are predominantly asymptomatic. In symptomatic patients, symptoms, such as epigastric murmur that increases by expiration especially after meals due to decreasing blood flow to the gastrointestinal tract organs because of the compression to the proximal celiac artery, nausea, vomiting, and weight loss, are frequently observed. In this article, we report a case of asymptomatic Celiac artery compression syndrome that was diagnosed through a suspicious physical examination in a 14-year-old male patient admitted to the pediatric rheumatology outpatient clinic due to bilateral knee pain. This article aims to emphasize the importance of detailed physical examination and the differential diagnosis of celiac artery compression syndrome especially in patients with abdominal discomfort and abdominal pain.

Keywords: Celiac artery compression syndrome, median arcuate ligament syndrome, stenosis

\section{Introduction}

Celiac artery compression syndrome is a clinical condition caused by compression of the celiac artery by the surrounding tissues (1). Various hypotheses have been proposed for the etiology of this disease; the first of these is abnormal location of the proximal celiac trunk resultsing in compression by the normally located
Address for Correspondence/Yazışma Adresi: Vildan Güngörer, Selçuk University Faculty of Medicine, Department of Pediatric Romatology, Konya, Turkey E-mail: vildan_61183@hotmail.com ORCID: orcid.org/0000-0002-9838-2603

Received/Geliş Tarihi: 16 March 2020 Accepted/Kabul Tarihi: 08 April 2020

This study was presented as a poster in the $6^{\text {th }}$ Erciyes Pediatrics Academy Winter Congress. median arcuate ligament (MAL); according to the other hypothesis, abnormally longer MAL compresses proximal part of the celiac artery (2). In addition, compression of the surrounding tissues, such as periaortic ganglionic tissue, fibrous band or stenosis caused by atherosclerotic plaques in elderly patients is also suspected in the etiology (1). Patients are predominantly asymptomatic. In symptomatic
Çölyak arter kompresyon sendromu çölyak artere çevre dokuların basısı sonucu oluşan klinik bir durumdur. Hastalar genellikle asemptomatiktir. Semptomatik hastalarda Çölyak arter proksimaline bası sonucu gastrointestinal sistem organlarına az kan akımı gitmesine bağlı olarak özellikle yemeklerden sonra ekspiryum ile artan epigastrik üfürüm, bulantı, kusma ve zayıflama gibi semptomlar öne çıkar. Bu yazıda bilateral diz ağrısı nedeniyle çocuk romatoloji polikliniğine başvuran 14 yaşında erkek hastada rutin fizik muayene sırasında şüphe duyulması sonucu saptanan asemptomatik bir Çölyak arter kompresyon sendromu olgusu sunulmuştur. Bu yazıdaki amacımız özellikle abdominal rahatsızlık hissi, karın ağrısı gibi semptomları olan hastalarda Çölyak kompresyon sendromunun da ayırıcı tanıda düşünülmesinin ve dikkatli fizik incelemenin önemini vurgulamaktır.

Anahtar Sözcükler: Çölyak arter kompresyon sendromu, medyan arkuat ligaman sendromu, stenozis istanbul Haseki Training and Research Hospital The Medical Bulletin of Haseki published by Galenos Yayinevi. 'Telif Hakkı 2020 Istanbul Haseki Eğitim ve Araşıırma Hastanesi Haseki Tıp Bülteni, Galenos Yayınevi tarafından yayınlanmışıı. 
patients, symptoms, such as epigastric murmur increasing by expiration especially after meals due to decreasing blood flow to the gastrointestinal tract because of the compression of the proximal celiac artery, nausea, vomiting, and weight loss are frequently observed $(3,4)$.

Abdominal computed tomographic angiography (CTA) and conventional angiography are useful for monitoring compression-induced stenosis of the proximal celiac trunk due to fibrous bands and arterial dilatation and collateral formation distal to this stenotic region (5). In symptomatic patients, postoperative results of surgical treatment by cutting and releasing the MAL are promising (5).

In this article, we present a case of asymptomatic celiac artery compression syndrome diagnosed on the basis of a thorough physical examination in a 14-year-old male patient who was admitted to the pediatric rheumatology outpatient clinic due to bilateral knee pain.

\section{Case}

A 14-year-old, $168 \mathrm{~cm}$ tall, weighing 49 kilograms male was admitted to our hospital with a five-year history of bilateral knee joint pain that increased with activity and decreased with analgesic use and rest. He denied a history of swelling, redness and increased temperature in the knee joints accompanying the pain. He complained of pain occasionally radiating to the entire leg, however, he did not report any complaints indicating other systems. There was no history of any diagnosis of a disease that could require regular medication, hospitalization or previous surgery. There was no family history of rheumatic diseases. The patient was referred to our outpatient clinic with a preliminary diagnosis of rheumatic disease. His vital signs and blood pressure in both arms were normal; however, physical examination revealed oropharyngeal hyperemia and postnasal seropurulant drainage. On cardiac examination, a grade 1-6 continuous murmur was auscultated in the apex. There was tenderness over the bilateral tuberosity on pressure. Laboratory tests were as follows: WBC: $5.3 \mathrm{~K} / \mathrm{uL}$, ANS: $2.87 \mathrm{~K} / \mathrm{uL}$, Plt: $340 \mathrm{~K}$ $\mathrm{UL}$, sedimentation: $37 \mathrm{~mm} / \mathrm{h}$, C-reactive protein: 13.2 (0-8) $\mathrm{mg} / \mathrm{L}$, ASO: $143 \mathrm{IU} / \mathrm{mL}$, Brucella serology was negative, other biochemical tests and complete urine analysis were normal and throat culture revealed normal flora. Knee radiograph was compatible with bilateral Osgood-Schlatter disease. Echocardiography was normal. Subcostal examination with pulse-wave Doppler revealed significantly increased flow velocity in the celiac trunk, and two-dimensional examination with color Doppler showed increased gradient in the celiac artery (Figure 1). During the repetition of the auscultation for further examination of the murmur, it was found that the murmur was present in the epigastric area. CTA was performed to visualize the aorta and its branches. CTA scan showed compression of the celiac artery by the MAL at a rate of $50 \%$ and stenosis and post stenotic dilatation at that site (Figure 2). No angiographic abnormalities were observed in the aorta and other branches. Based on the asthenic body type of the patient and the CTA findings, the patient was diagnosed with celiac artery compression syndrome. Regular followup was recommended as he was asymptomatic for the syndrome. Knee pain, which was the reason for admission to the outpatient clinic, was consistent with bilateral Osgood-Schlatter disease.

\section{Discussion}

Celiac artery compression syndrome is also known as MAL syndrome (MALS) or as Dunbar syndrome. The syndrome was firstly described in 1963 by Harjola (6) in a patient with mesenteric ischemia caused by external

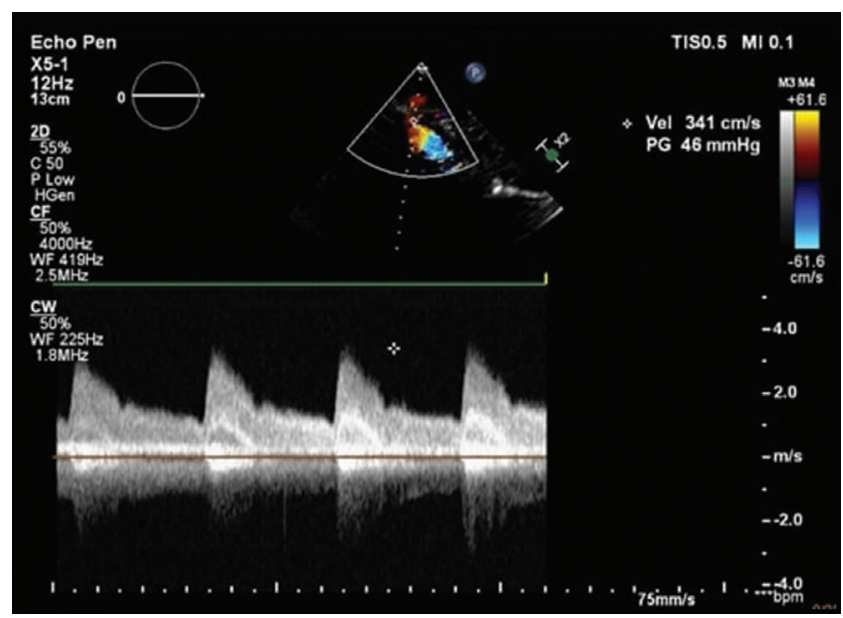

Figure 1. Increased gradient on the celiac artery in color doppler measurements

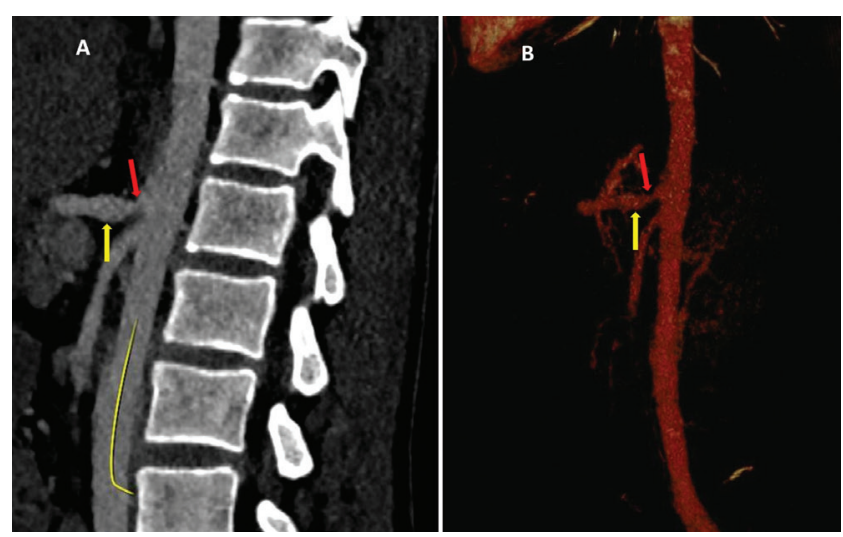

Figure 2. Contrast-enhanced abdominal CT (A) and CTangiography images show stenosis (red arrow) and post-stenotic dilatation (yellow arrow) immediately after the origin of the celiac artery (B)

CT: Computed tomography 
compression of the celiac artery. Dunbar et al. (7) performed surgical release of the MALs in 15 patients with celiac artery compression syndrome in 1965. Due to the closer anatomical location of the MAL to the celiac artery in females, the syndrome is more frequent than in males. Anatomical variations are important in etiological aspects (8). The symptoms are on the occasion of a decrease in blood flow due to compression of the celiac artery at the aortic outlet by the MAL. Two theories have been proposed to explain symptoms in MALS. The first theory suggests mesenteric ischemia development by decreased blood flow because of the compression. The second claims that the syndrome develops by neurogenic stimulation because of a celiac ganglion or plexus compression that may result in irritation of sympathetic pain fibers (9). In symptomatic cases, postprandial abdominal pain, weight loss, nausea, vomiting, diarrhea, loss of appetite and abdominal discomfort are frequently seen. Especially during expiration, due to the pressure of the ligament resulting from the movement of the diaphragm to the cranial region, celiac pressure increases further and the symptoms become more prominent.

However, some patients are asymptomatic despite severe stenosis of the celiac artery. It is known that the incidence of isolated celiac artery stenosis in asymptomatic individuals is between $2.3 \%$ and $7.2 \%$. In autopsy series, this rate increases by up to $24 \%$ (10). Although celiac artery stenosis is so frequent, the fact that the majority of cases do not develop celiac artery compression syndrome can be explained by that the stenosis of the celiac artery is minimal, tolerable, or shows normal flow patterns due to collaterals from the superior mesenteric artery (SMA) to the celiac artery or its branches. The most common collateralization is from the gastroduodenal artery (11). The main complaint of our patient was leg pain which did not have any diagnostic value for celiac artery compression syndrome, yet the murmur in the epigastric region during the physical examination suggested a clinical suspicion of this syndrome.

Methods such as Doppler ultrasound (DUS), spiral CTA, selective conventional angiography, and magnetic resonance angiography can be applied for the diagnosis of celiac artery compression syndrome in order to visualize the compression of the celiac artery $(12,13)$. Although the gold standard diagnostic method is selective conventional angiography, CTA is more in use because its non-invasive nature (12). Stenosis can be monitored by CTA, especially in sections in the lateral position $(11,14,15)$. Thus, our case was diagnosed by CTA after the epigastric murmur was auscultated on physical examination. Follow-up was chosen as he was asymptomatic and was detected through a detailed physical examination.
The aim of treatment in patients with celiac artery compression syndrome is to normalize celiac artery blood flow to eliminate symptoms. This aim can be achieved by cutting the MAL via open or laparoscopic surgical techniques, and the surgical procedure is reported to be successful in many published cases and case series.

In conclusion, in spite of our patient had no symptoms, during the careful physical examination of the patients with various complaints related to the abdominal region, it is likely to be diagnosed by auscultation of murmur in the epigastric region and thus the help of advanced imaging techniques. The aim of this article was to emphasize the importance of detailed physical examination and the differential diagnosis of celiac artery compression syndrome especially in patients with abdominal discomfort and abdominal pain. We consider that our case is important as limited cases of the pediatric celiac artery compression syndrome have been reported in the literature.

\section{Authorship Contributions}

Concept: V.G., A.S., Ş.A. Design: V.G., A.S. Data Collection or Processing: V.G. Analysis or Interpretation: V.G., A.S., M.Ö., Ş.A. Literature Search: V.G., A.S., M.Ö., S.A. Writing: V.G.

Conflict of Interest: No conflict of interest was declared by the authors.

Financial Disclosure: The authors declared that this study received no financial support.

\section{References}

1. Grotemeyer D, Duran M, Iskandar F, Blondin D, Nguyen K, Sandmann W. Median arcuate ligament syndrome: vascular surgical therapy and follow-up of 18 patients. Langenbecks Arch Surg 2009;394:1085-92.

2. Watson WC, Sadikali F. Celiac axis compression: Experience with 20 patients anda critical appraisal of the syndrome. Annals of Internal Medicine 1977;86:278-84.

3. Horton KM, Talamini MA, Fishman EK. Median arcuate ligament syndrome: evaluation with CT angiography. Radiographics 2005;25:1177-82.

4. Alehan D, Dogan OF. Pediatric surgical image. A rare case: celiac artery compression syndrome in an asymptomatic child. J Pediatr Surg 2004;39:645-7.

5. Ilica AT, Kocaoglu M, Bilici A, et al. Median arcuate ligament syndrome: multidetector computed tomography findings. J Comput Assist Tomogr 2007;31:728-31.

6. Harjola PT. A rare obstruction of the coeliac artery. Ann Chir Gynaecol Fenn 1963;52:547-50.

7. Dunbar JD, Molnar W, Beman FF, Marable SA. Compression of the celiac trunkand abdominal angina: preliminary report of 15 cases. American Journal of Roentgenology 1965;95:73144. 
8. Loukas M, Pinyard J, Vaid S, Kinsella C, Tariq A, Tubbs RS Clinical anatomy of celiac artery compression syndrome: a review. Clin Anat 2007;20:612-7.

9. Chou JW, Lin $C M$, Feng $C L$, Ting $C F$, Cheng $K S$, Chen YF. Celiac artery compression syndrome: an experience in a single institution in taiwan. Gastroenterol Res Pract 2012;2012:935721.

10. Park CM, Chunk JW, Kim HB, Shin SJ, Park JH. Celiac Axis Stenosis: Incidence and Etiologies in Asymptomatic Individuals Korean Journal of Radiology 2001;2:8-13.

11. Ikeda O, Tamura $Y$, Nakasone $Y$, Yamashita $Y$, Celiac artery stenosis/occlusion treated by interventional radiology. Eur J Radiol 2009;71:369-77.
12. Karahan Öi, Kahriman G, Yikilmaz A, Ok E. Celiac artery compression syndrome: diagnosis with multislice CT. Diagn Interv Radiol 2007;13:90-3.

13. Gürol Ö, Yücel Ü, Mehmet I, Arif Ö, Ahmet Ö, Burhan K. Celiac artery compression syndrome: Report of a case and literature review. The Turkish Journalof Gastroenterology 1999;10:161-3.

14. Kopecky KK, Stine SB, Dalsing MC, Gottlieb K. Median arcuate ligament syndrome with multivesselinvolvement: diagnosis with spiral CT angiography. Abdom Imaging 1997;22:318-20.

15. Scholbach T. Celiac artery compression syndrome in children, adolescents, and young adults: clinical and color duplex sonographic features in a series of 59 cases. J Ultrasound Med 2006;25:299-305. 